Nota / Note

\title{
A RAPID METHOD FOR MEASURING SOIL WATER CONTENT IN THE FIELD WITH A AREOMETER
}

\author{
Adonai Gimenez Calbo \\ Embrapa Hortaliças, C.P. 0218 - CEP 70359-970 - Brasília, DF - e-mail <adonai@cnph.embrapa.br>
}

\begin{abstract}
The availability of a rapid method to evaluate the soil water content $(U)$ can be an important tool to determine the moment to irrigate. The soil areometer consists of an elongated hydrostatic balance with a weighing pan, a graduated neck, a float and a pynometric flask. In this work an areometer was adapted to rapidly measure soil water content without the need of drying the soil. The expression $U=\left(M_{A}-M_{A D}\right) /\left(M_{M}-M_{A}\right)$ was used to calculate the soil water content. In this equation $M_{M}$ is the mass to level the areometer with the pycnometric flask filled with water, $M_{A}$ the mass to level the areometer with a mass $M_{M}$ of soil in the pycnometer, the volume being completed with water, and similarly $M_{A D}$ the mass added to the pan to level the areometer with a mass $M_{M}$ of dried soil in the pycnometric flask. The convenience of this method is that the values $M_{M}$ and $\mathrm{M}_{\mathrm{AD}}$ are known. Consequently, the decision on irrigation can be made after a measurement that takes, about, ten minutes. The procedure involves only stirring the soil with water for at least 2 minutes to remove the adhered air. The soil water content data obtained with the areometric method were similar to those obtained weighing the soil before and after drying to constant weight, in an oven at $105^{\circ} \mathrm{C}$.

Key words: hydrostatic balance, irrigation moment, pycnometer, soil humidity
\end{abstract}

\section{MEDIDA RÁPIDA DA UMIDADE DO SOLO EM CAMPO COM UM AREÔMETRO}

\begin{abstract}
RESUMO: Métodos rápidos de medir a umidade gravimétrica do solo, massa de água dividida pela massa seca do solo $(U)$, podem ser importantes para determinar o momento da irrigação. Neste trabalho descrevese um areômetro de solo para a medição rápida da umidade do solo, com um procedimento que elimina a necessidade da secagem. $O$ areômetro descrito é uma balança alongada com um prato de pesagem, um pescoço graduado, um flutuador e um frasco picnométrico. $A$ umidade foi calculada com a expressão $U=\left(M_{A}\right.$ - $\left.M_{A D}\right) /\left(M_{M}-M_{A}\right)$. Nesta expressão $M_{M}$ é massa para nivelar o areômetro com o frasco picnométrico cheio de água, $M_{A}$ a massa para nivelar o areômetro com o frasco picnométrico cheio de água após a adição da massa $M_{M}$ de solo, e $M_{A D}$ foi a massa necessária para nivelar o areômetro com água e uma quantidade $M_{M}$ do solo seco. Neste procedimento $M_{M}$ e $M_{A D}$ são conhecidos, assim, a decisão sobre o momento da irrigação é feita após uma medição de umidade em cerca de dez minutos. O método areométrico gerou resultados de umidade do solo similares ao método gravimétrico, no qual a massa de água e a massa de solo seco são obtidas com o emprego de secagem em estufa a $105^{\circ} \mathrm{C}$ até peso constante.

Palavras-chave: balança hidrostática, momento da irrigação, picnômetro, teor de água
\end{abstract}

\section{INTRODUCTION}

In less developed regions the gravimetric procedure to measure soil water content and other related simplified procedures are the most frequently methods used, since tensiometers, psicrometers and neutron probes are considered expensive equipments.

With a pycnometric procedure, Leite et al. (1994) measured the soil water content without drying the samples. For this rapid procedure, they measured the total mass of a pycnometer completed with water, after the addition of a specified amount of soil. They used the notions of mass, density and buoyance to measure soil water content with a $0.1 \mathrm{~g}$ accuracy field balance. Another instrument that can be used to measure mass and density of particles, is the Nicolson areometer (Rheinboldt, 1988), also named Nicolson balance.
Consequently a modification of this areometer could be developed to measure these variables required for the application of the Leite et al (1994) method.

In this article an adaptation of this method is made, to measure soil water content and density using an areometer, along with specifications about this new soil areometer. The areometric procedure to measure soil water content, with and without the extraction of the air bubbles with vacuum, was compared to the traditional gravimetric method using a Red Yellow Latossoil of the Cerrado, from Brasília, DF, Brazil.

\section{MATERIAL AND METHODS}

\section{Soil areometer}

The areometer (Figure 1, right) is an elongated balance with boyance center, close to the water surface, 
and a deep mass center to obtain stability. Above the float a $20^{\circ}$ cone was used to soften the shape transition to a cylinder with $0.1 \mathrm{~mL}$ divisions. The divisions are $2.0 \mathrm{~mm}$ apart. This soft cone-cylinder transition assures that the water surface tension does not cause sudden areometer sinking, while soil is being added to the pan. The concave pan has a large central orifice in which a cork transversed by a pole, rests on the top of the measuring cylinder. The whole set, called areometer balance, floats in a two liter provete.

The abraded pycnometric glass mouth is coupled to a nylon cap, below the float base (Figure 1, center). The cap orifice avoids pressurization during fixation. Soil is transferred to the pycnometric flask by pushing the cork pole (Figure 1, left).

Soil mass is evaluated in the areometer balance using a set of weights consisting of: one $1.000 \mathrm{~g}$ piece; two $2.000 \mathrm{~g}$; one $5.000 \mathrm{~g}$, one $10.000 \mathrm{~g}$ and two 20.000 $\mathrm{g}$ pieces. These cylindrical bronze weight pieces were prepared to achieve exact weights by abrasion, followed by accurate weighing using an analytical balance. This weight set allowed the measurement of masses from 0 to $50 \mathrm{~g}$. The $0.1 \mathrm{~g}$ precision is obtained through readings at the graduated cylinder.

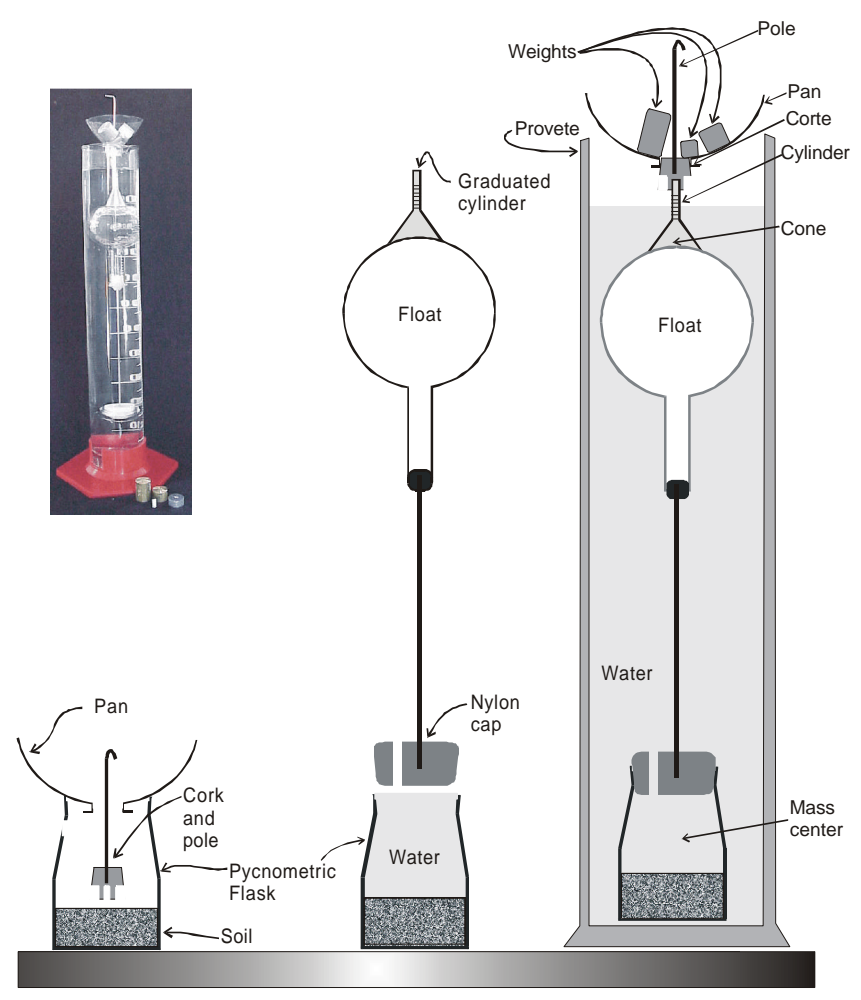

Figure 1- Soil areometer to measure soil density and water content. The top left side is a photography of the equipment here used, with the standard weights in the plate and water in the pycnometric flask. At the base (left), the soil weighed by the areometer is transferred to the pycnometric flask. At the center, the float is being inserted on the pycnometric flask. At the right the areometer is floating during a measurement.

\section{Water content and density}

The soil water content $U$ is given by:

$\mathrm{U}=\mathrm{M}_{\mathrm{WA}} / \mathrm{M}_{\mathrm{S}}$

where $M_{W A}$ is the soil water mass and $M_{S}$ the soil particle dry mass.

Since soil particle density does not change with soil water content the method of soil immersion in water can be used to measure water content, as described by Leite et al. (1994).

For the measurement of soil water content the following masses are needed: $M_{M}$, of the soil placed on the pan that takes the aerometer to level zero, in relation to the water surface; $M_{A}$ the mass for zeroing the pycnometric flask with a $M_{M}$ mass of wet soil, completed with water; and $\mathrm{M}_{A D}$ the mass for zeroing, when the pycnometric flask completed with water contain a mass $M_{M}$ of dry soil.

A $M_{M}$ wet soil mass density $\rho_{W}$ occupies a volume equal to the ratio between $M_{M}$ and $\rho_{w}$. This is a volume that multiplied by the water density $\left(\rho_{\mathrm{WA}}\right)$ is the mass of water displaced by the soil immersion. Thus, $M_{A}$ represents a reduction in the apparent soil mass due to immersion. $M_{A}$ can be expressed by:

$M_{A}=M_{M}-M_{M} \rho_{W} /\left(\rho_{W}-\rho_{w A}\right)$

For a wet soil, $M_{M}=M_{S}+M_{W A}$. Thus, replacing $\rho_{\mathrm{W}}$ by the dry soil density $\left(r_{D}\right)$ Eq. 2 can be presented in the form:

$M_{A}=M_{M}-M_{S} r_{D} /\left(r_{D}-r_{W A}\right)$

For a dry soil Eq. 2 can be rewritten with the introduction of the subscript $D$, to represent the mass $\left(\mathrm{M}_{\mathrm{AD}}\right)$ and the density $\left(\rho_{\mathrm{D}}\right)$ :

$M_{A D}=M_{M}-M_{M} r_{D} /\left(r_{S}-r_{W A}\right)$

From Eq. 3 an expression to obtain $M_{S}$ as a function of $M_{A}$ and $M_{M}$ is:

$M_{S}=\left(M_{M}-M_{A}\right)\left(\rho_{D}-\rho_{W A}\right) / \rho_{D}$

Subtracting Eq. 3 from Eq. 4 the difference $M_{M}-M_{S}$ is obtained. This difference is equal to the amount of water $\left(\mathrm{M}_{\mathrm{WA}}\right)$.

$M_{W A}=\left(M_{A}-M_{A D}\right)\left(\rho_{D}-\rho_{W A}\right) / \rho_{D}$ obtained:

Dividing Eq. 5 by Eq. 6 the soil water content is

$U=\left(M_{A}-M_{A D}\right) /\left(M_{M}-M_{A}\right)$

The wet soil density is calculated with Eq. 8, obtained from Eq. 2:

$\rho_{W}=\rho_{W A} M_{M} / M_{A D}$

For field use the water density $\left(\rho_{\mathrm{WA}}\right)$ can be taken as $1.000 \mathrm{~kg} \mathrm{~L}^{-1}$. 


\section{Procedure}

$M_{M}, M_{A}$ e $M_{A D}$ are measured as follows: $M_{M}-$ The pycnometric flask is filled with water and inserted on the areometer, which floats in water. Weights are added to sink the areometer up to the graduated neck. This weight added to the observed displaced water with aid of the neck scale, is the reading. This mass can also be measured adding water to the pan with a pipette. The areometer used in this work had an $M_{M}$ value of $35.2 \mathrm{~g}$.

$M_{A}-A M_{M}$ soil sample is quantitatively transferred to the pycnometric flask (Figure 1). Water is added to the pycnometric flask and the soil is stirred with a stick during 3 minutes to remove air bubbles. After two minutes of sedimentation, the volume is completed adding water to the rim, slowly, avoid turbulence. The filled pycnometric flask is inserted on the areometer and the mass needed to take the level to zero is $M_{A}$

$M_{A D}$ - is measured with dry soil following the same steps described in the previous item, to determine $M_{A}$.

During field measurements only $M_{A}$ is determined. $M_{M}$ is a characteristic of the areometer and $M_{A D}$ is a previously obtained value for the soil under consideration, dried to constant weight at $105^{\circ} \mathrm{C}$.

This areometer was evaluated using a completely randomized assay of soil samples, with four replicates. The treatments were soil water content measurements, made according to: i. gravimetric method; ii. areometric method using standard weights, and iii. by adding water with a graduated pipette.

\section{RESULTS AND DISCUSSION}

The soil areometer (Figure 1) is simple to build and is handled as a balance with the addition of masses. This soil areometer was designed for rapid operation. The use of a $0.1 \mathrm{~mL}$ graduated neck reduced the sensibility, but avoided the need of weight pieces smaller than $1 \mathrm{~g}$.

Measurements with similar sensibility can be made with a $10 \mathrm{~mL}$ graduated pipette (Table 1). From a practical stand point, however, this requires an additional step in which the areometer pan and cork are dried.
The time to perform a measurement was always inferior to $10 \mathrm{~min}$. These measurements have to be made in a room with wind protection. The values of $M_{M}$ and $M_{A D}$ should be on hand for the calculation of the soil water contents through $M_{A}$ measurements.

A question that could be raised in the Leite et al. (1994) method is if a simple soil stirring procedure in water is enough to remove all the adhered air by the soil. The estimates of density versus stirring time were indicative that in a few minutes most of the air is removed from the soil. However, even after $15 \mathrm{~min}$ the density was slightly smaller than when measured after vacuum extration ( $2.632 \pm 0.009)$. There are no benefits on stirring the soil sample for more than $3 \mathrm{~min}$ (Figure 2).

In all cases the areometric estimates of soil water content were similar to the gravimetric estimates. An advantage of the areometric method and the pycnometric method (Leite et al., 1994) is to obtain results in a few minutes. This short time allows decisions on irrigation scheduling, without delay. More than 30 areometric measurements can be performed a day. As a limitation, the areometric method should only be used for substrates that do not suffer intrinsic density changes in time. For organic substrates which degrade slowly, the areometric method can be used only if the value $O M_{A D}$ is periodically updated.

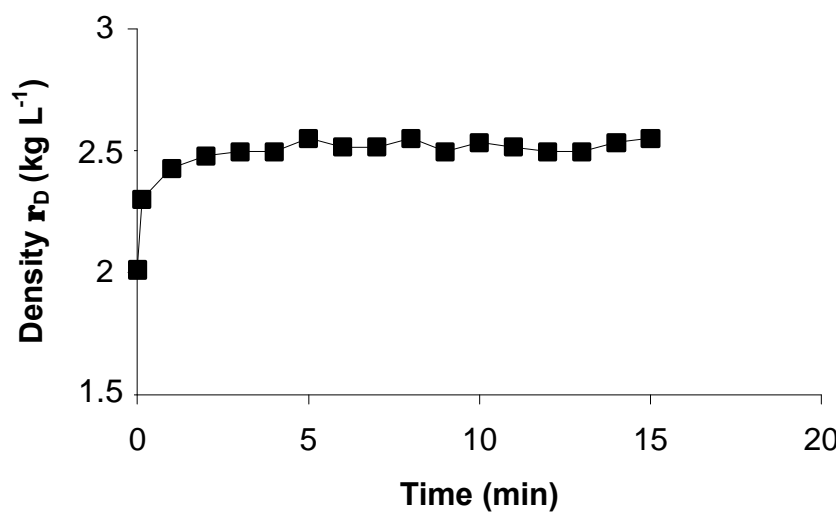

Figure 2 - Density of dry soil particles as function of the stirring time used to remove the air bubbles from the soil in the water suspension.

Table 1- Soil water content measurements with the soil areometer in comparison to the gravimetric method. The soil mass $M_{M}$, the apparent mass of wet soil in water $M_{A}$ and the dry soil apparent mass in water $M_{A D}$ were used to calculate soil water content (Eq. 2). These variables were measured with a set of standard weights and with the addition of water using a graduated $10 \mathrm{~mL}$ pipette. Each result is the average of four replicates \pm the standard error.

\begin{tabular}{lccccc}
\multirow{2}{*}{$\begin{array}{c}\text { Gravimetric soil } \\
\text { water content }\end{array}$} & \multicolumn{2}{c}{ Areometric soil water content $\left(\mathrm{g} \mathrm{H}_{2} \mathrm{O} \mathrm{g} \mathrm{g}^{-1}\right.$ dry soil) } \\
\cline { 2 - 3 } \cline { 2 - 3 } \cline { 5 - 6 } & weighing & & \multicolumn{2}{c}{ Vacuum extraction } \\
\hline 0.00 & $0.000 \pm 0.002$ & $0.000 \pm 0.002$ & & $0.000 \pm 0.003$ & $0.000 \pm 0.003$ \\
$0.0619 \pm 0.0004$ & $0.056 \pm 0.004$ & $0.057 \pm 0.003$ & & $0.061 \pm 0.003$ & $0.062 \pm 0.002$ \\
$0.1342 \pm 0.0018$ & $0.129 \pm 0.005$ & $0.132 \pm 0.006$ & & $0.125 \pm 0.002$ & $0.128 \pm 0.002$ \\
$0.1811 \pm 0.0007$ & $0.179 \pm 0.002$ & $0.179 \pm 0.003$ & & $0.175 \pm 0.002$ & $0.173 \pm 0.003$ \\
$0.2417 \pm 0.0011$ & $0.239 \pm 0.007$ & $0.237 \pm 0.006$ & & $0.233 \pm 0.003$ & $0.233 \pm 0.003$ \\
\hline
\end{tabular}




\section{ACKNOWLEDGMENTS}

To professor N.A. Villa Nova and to our staff members João Batista Gomes and José Carlos Rodrigues da Silva.

\section{REFERENCES}

ERBACH, D.C. Measurement of soil bulk density and moisture. Transactions of the ASAE, v.30, p.922-931, 1987.
LEITE, J.A.; VILLA NOVA, N.A.; REICHARDT, K. Improvement of the simple and rapid immersion method of soil water determination. Soil Technology, v.7, p.19-24, 1994.

RHEINBOLDT, H. História da balança e a vida de J.J. Berzelius. São Paulo: Nova Stella; EDUSP, 1988. 293p.

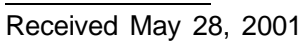

